\title{
Fred Cassidy: Who DAREs wins
}

\author{
TOM M CARTHUR reflects on the long \\ and fruitful life of Frederic Gomes \\ Cassidy, who died on 14 J une 2000, \\ aged 93.
}

There are many kinds of lexicography, and many kinds of lexicographer. I was fortunate enough to know this particular lexicographer of English - of other than standard English - since 1983, often wishing I'd had the chance to know him sooner and better. He was a most appropriate scholarly lexicographer for the century through so much of which he lived, and it was always a pleasure corresponding with him both as a contributor to and a reader of ET and when he was writing entries for The Oxford Companion to the English Language on Caribbean usage, dialectology, and lexicography.

Fred was a good friend of English Today, and paid attention not just to its contents but even to the photographs of the contributors, believing (as I do) that it was good to have contributors' pics in a review of this kind, but wishing (as I have often done) that the quality - and availability - of the photos could be more consistent. In addition, just now and then, a heavy and hefty volume would arrive in Cambridge, England from Cambridge, Massachusetts and the Belknap Press of Harvard University Press enormous instalments of the maximum opus he'd begun in 1963: the Dictionary of American Regional English (whose acronym is, most appropriately, DARE). The first volume (A-C: 903 pages) came in 1985, the second (D-H: 1,175 pages) in 1991, the first two volumes of five. And the work goes on in Madison, Wisconsin - a national epic undertaken by a remarkable team, and a monument to one man's enthusiasm, endurance, and vision.

Frederic ('no k') Cassidy was born in Kingston, Jamaica, in 1907, and obtained his B.A. and M.A. from Oberlin College and his doctorate from the University of Michigan. He taught at both Oberlin and Michigan, as well as at the Université de Strasbourg, Columbia, Stanford, the University College (now University) of the West Indies, and most particularly at the University of Wisconsin at Madison, where he was based from 1939 onwards - that is, from when I was a one-year-old in Glasgow, Scotland.

$\mathrm{H}$ is publications include A Method for Collecting Dialect (1953), The Devel opment of Modern English (1954), Jamaica Talk (1961), and the Dictionary of J amaican English (with Robert Le Page: 1967, revised 1980). Among his many roles were President of the American Dialect Society (1959-61) and President of the Society for Caribbean Linguistics (1972-74). Already a pioneering Caribbeanist by the Sixties, he had become a significant Americanist long before the first volume of DARE appeared, notably as a lexicographer not of a mainstream standard kind, like most professional lexicographers, but of the highways and by-ways of language, where real people live and work, and talk about their local equivalents of black gnats (or punkies), brown betties (or apple betties), cedar savages, chisel-chins, dragsaw men, fish-drownders, and of course gaums.

J oan Hall, Fred's colleague and successor in the DARE project, put it as follows in the Fall 2000 issue (14:2) of the newsletter of the Dictionary Society of North America: 'Fred's love of language resulted in large part from his exposure to both standard and Creole varieties of English in Jamaica, where he lived for his first eleven years, and his introduction to yet another dialect when he moved to Akron, Ohio in 1918. The realization that it was he rather than his new classmates who sounded "funny" was the stimulus to learn all he could about this varied language of ours' - by which she meant what H. L. Mencken entirely rightly called 'the American language'.

My first enthusiasm for Fred's work was his pioneering Jamaican volume with Robert Le Page (also a contributor to English Today, with 'Acts of Identity' in ET8, Oct 86) and, like ET, published by Cambridge University Press. This book is for me the founding document of Caribbean lexicography, followed magnificently in 1996 by Richard Allsopp's Dictionary of Caribbean English Usage (Oxford University Press, 1996), which Richard himself described 


\title{
Not a rapid science
}

\author{
We reproduce here the closing paragraphs of the Acknowledgements \\ section of Volume I of the Dictionary of American Regional English.
}

Lexicography, which by its nature demands a high degree of accuracy in detail, is not a rapid science. The DARE project, begun in 1965, has advanced steadily in these twenty years. Data have been collected and prepared. Problems of limitation and presentation have been worked out. Volume I is now complete, and considerable work has been done toward the remaining volumes. With continued support, it should be possible to complete these within a few years. DARE has had the great benefit of popular interest all along - the warm collaboration without which such a piece of work could hardly be accomplished. To all who have helped in any way, our grateful thanks.

As a personal note, the Chief Editor adds the following lines of dedication to his wife, Professor Hélène Monod Cassidy (1909-1980):

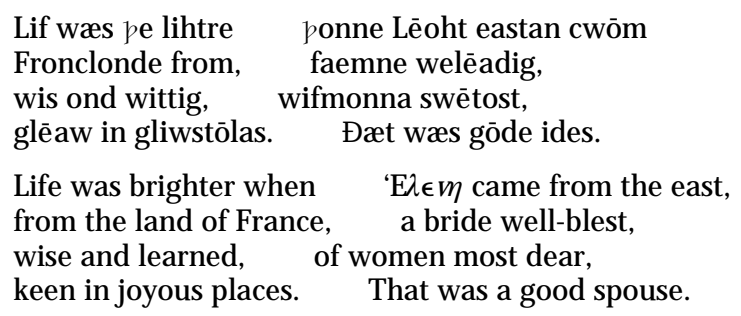

in 'Cataloguing the Caribbean' (ET51, J ul 97). American English, both formal and informal, has been an unarguably significant variety of English since Noah Webster's lifetime, 200 or so years ago. The vibrant and varied usage of the Caribbean is not yet so fully and freely accepted by the world - or indeed in the Caribbean itself - but when it is, the list of its path-finders will include Cassidy, Le Page, and Allsopp.

On one page alone of the 2 nd edition of the DCEU one can find the following headwords: calemsha, calepeaver, calibash, calibean, calico weed, caliloo, calimbe, calipash, calipee, calipeva/calipaver, call, callalloo/callalu, callawampus, call-dog, callepee, callipach, calipash, callipe, callipee, calulu, cameroun $(\mathrm{g})$, camfor yam, camiejer, campeachy logwood, camphor bush/weed, camphor tree, camphor yam, can, and Canada fleabane. All of them English words every one, whatever the purists may say - all as legitimate (though maybe not quite so upmarket) as asphyxiate, physiognomy, and tergiversation. The OED now struggles to catalogue all such world English words (see page 46), and by and large thoughtful folk can see the reason for it. If they do, then the likes of Fred Cassidy may already be among their heroes.

When I wrote to Fred in the summer of 1987 , to ask him if he would join the team for the Oxford Companion to the English Language, he wrote back: 'What a good idea, to have a Companion to the Companion to English Literature! I'll gladly participate.' We had earlier that same year been involved with an article of his ('The fallible computer and DARE', ET9: J an 87) and with a not entirely complimentary complementary piece in the same issue by the US writer on language Robert Claiborne: 'The politics of dialect.' So, in this same letter, Fred referred with thanks to my - naturally - providing him with space to reply (which he had done, vigorously). His comments in the letter indicate both his warmth and his word play: Thanks for giving my riposte to Claiborne full space in English Today. I don't know how he'll take it but I bear him no ill will. We are all born of clay, aren't we! My share is not only in the feet.'

Common clay, maybe - but an uncommon man. 